\title{
Critical Particle Size for the Formation of Ceria-Zirconia Solid Solution by Solid Phase Reaction near Room Temperature Estimated from Average Particle Size
}

\author{
Akihiko SUDA, Hideo SOBUKAWA, Toshio KANDORI, Yoshio UKYO and Masahiro SUGIURA \\ Toyota Central Research \& Development Laboratories Incorporated, 41-1, Yokomichi, Nagakute, Nagakute-cho, Aichi-gun, Aichi 480-1192
}

\author{
室温付近の固相反応によるセリアージルコニア固溶体の生成の際の, \\ 平均粒子径から推測した臨界粒子径 \\ 須田明彦·曽布川英夫・神取利男·右京良雄・杉浦正洽 \\ (株) 豊田中央研究所, 480-1192 愛知県愛知郡長久手町長淡横道 41-1
}

\begin{abstract}
The formation of ceria-zirconia solid solution by the solid phase reaction of ceria and zirconia powders near room temperature during wet attrition milling was recently reported. The solid phase reaction occurred as a result of a large plastic deformation, breaking and mutual combining on the ceria particle as well as the solid solution. The size of the particle in which the solid phase reaction can occur was examined in this study. The reaction that forms ceria-zirconia solid solution from large ceria particles $\left(4 \mathrm{~m}^{2} / \mathrm{g}\right)$ begins when the average particle size reaches $28 \mathrm{~nm}$ or smaller. The reaction does not occur in $\mathrm{CeO}_{2}$ powder with particle size larger than $30 \mathrm{~nm}$. The critical particle size of ceria powder to begin the reaction with zirconia is thought to be approximately $20 \mathrm{~nm}$, which was found asymptotically by two methods, X-ray diffraction and specific surface area measurements. [Received June 19, 2000; Accepted March 22, 2001]
\end{abstract}

Key-words : Ceria-zirconia solid solution, Critical particle size, Attrition mill, Solid phase reaction

\section{Introduction}

Ceria-zirconia solid solution is a useful material as a catalytic promoter in three-way catalysts for purifying automotive exhaust. For this use, the material must have a large specific surface area as well as a small particle size. The occurrence of the low-temperature formation of ceria-zirconia solid solution by milling ceria $\left(\mathrm{CeO}_{2}\right)$ powder with milling media made of zirconia $\left(\mathrm{ZrO}_{2}\right)$ in ethanol ${ }^{1), 2)}$ was previously found by the present authors. Ceria-zirconia solid solution is suitable for this purpose. One of the important characteristics of the material is oxygen storage capacity. The ceria-zirconia solid solution fabricated by attrition milling has a large oxygen storage capacity. ${ }^{3}$ )

Trovarelli et al. reported that ceria-zirconia solid solution having a specific surface area of approximately $20 \mathrm{~m}^{2} / \mathrm{g}$ could be fabricated by high-energy mechanical milling in dry conditions. ${ }^{4}$ Milling in dry conditions generally cannot easily fabricate small particles in the sub-micrometer region, because the cohesion of each particle becomes so strong that the particles cannot be broken down effectively into a smaller size in the region. Milling in wet conditions is thought to be more suitable for fabricating smaller particles having a larger specific surface area than dry conditions. However, no other study than that conducted by the present authors has been carried out for fabricating the solid solution by milling in wet conditions. The formation of the solid solution was proved to result from the solid phase reaction between ceria and zirconia powders near room temperature, and is enhanced by the contact stress between them. ${ }^{5)}$

Powders that can easily deform plastically such as aluminium metal powder are known to make alloys easily in the milling process with relatively moderate mechanical energy. This phenomenon is termed "mechanical alloying." To the best of our knowledge, other than that mentioned above, there has been nothing reported regarding the "mechanical alloying" of oxide particles, which are intrinsically brittle and hard. The mechanical properties of the material which composes a particle, and the particle di- ameter determine whether the particle will break down into a smaller size or deform plastically. Therefore, materials generally have an intrinsic particle size at which every material can deform and form an alloy or a solid solution. The intrinsic particle size is called the "critical" particle size here. If particles having a size less than the critical value undergo plastic deformation by mechanical milling, then the particles would fuse with one another to form a solid, and their diameter would increase up to the critical value.

In the forming process of ceria-zirconia solid solution, a large particle of ceria was milled to a size of around $20 \mathrm{~nm}$ and a particle much smaller than $20 \mathrm{~nm}$ was found to increase to approximately $20 \mathrm{~nm}$. The particle size of $20 \mathrm{~nm}$ was thought to be the "critical" particle size at which ceria particles react to form a solid solution with zirconia by wet milling at room temperature. ${ }^{5}$ ) The critical particle size is the upper size limit of the ceria particle able to form a solid solution with zirconia in the solid phase by wet milling. The critical particle size cannot be measured directly but, instead, can be estimated from the average particle size measured by the specific surface area and the half-width of the Xray diffraction pattern. In the previous study, the lattice constant of ceria was observed to gradually decrease, reaching the final value of the solid solution for the fine ceria powder of $7 \mathrm{~nm} .{ }^{5)}$ However, a detailed study of the forming process was not carried out for the coarse ceria powder as a starting material, particularly that for the beginning of the formation of the solid solution. Therefore, X-ray diffraction analysis was performed to study the formation mechanism of the ceria-zirconia solid solution formed from coarse $(200 \mathrm{~nm})$ ceria particles.

\section{Experimental}

An attrition mill was used for preparing samples. The milling apparatus used was an attrition mill, which is the same as that used in our previous experiment. ${ }^{5}$ The milling media of the mill consists of balls, a vessel and agitator disks made of zirconia containing $3 \mathrm{~mol} \% \mathrm{Y}_{2} \mathrm{O}_{3}$ (yttria partially 
stabilized zirconia). The agitator disks were rotated at 4200 $\mathrm{rpm}$. The acceleration applied to the balls charged in the vessel of the mill becomes approximately 1000 times larger than gravity at the rotational speed of $4200 \mathrm{rpm}$. Ceria powder (Wako Pure Chemical Industries), which has a specific surface area of $4 \mathrm{~m}^{2} / \mathrm{g}$, an average agglomerated grain size of $3 \mu \mathrm{m}$, and the purity of $99.9 \%$, was used as a starting material. Ethanol of the purity of $99.5 \%$ was used as the dispersant. A slurry containing $100 \mathrm{~g}$ of ceria powder was milled to study the change of the grain size or the specific surface area with milling. As milling proceeds, zirconia powder is supplied from the balls, vessel and agitator disks as a result of the abrasion between them. The supplied zirconia (containing $3 \mathrm{~mol} \% \mathrm{Y}_{2} \mathrm{O}_{3}$ ) acts as a chemical agent to form the solid solution. The specimen milled for a certain number of hours was examined by the X-ray diffraction method using $\mathrm{Cu} \mathrm{K} \alpha$ radiation. The specific surface area of the powders was measured using the single point BET (after Brunauer, Emmett and Teller) method, and the particle size was estimated from the surface area. The crystallite size was estimated by the half-width of the X-ray diffracted from the specimen using Scherrer's formula. ${ }^{6)}$ The amount of worn zirconia powder mixed from the milling media into the ceria powder was estimated from the weight loss of the milling media. The obtained data are examined by comparison with those of the solid solution powder made from ceria powder having a fine particle size, which corresponds to the powder fabricated in the previous study. ${ }^{2,5}$ )

\section{Results and discussion}

Total weight loss of the milling media was $65.2 \mathrm{~g}$ after $44 \mathrm{~h}$ of milling. This weight loss corresponds to the amount of worn zirconia powder mixed into the slurry of the ceria powder. The amount is almost the same as that in the experiment on the fine ceria powder described in our previous paper.5) Therefore, the wear rate of the media during milling for the fine and coarse ceria powders is almost the same.

$\mathrm{X}$-ray diffraction patterns of the fine ceria powder are shown in Fig. 1, which is referenced from our previous paper. ${ }^{2)}$ The X-ray diffraction line of the fine ceria powder remained at the same position from 0 to $4 \mathrm{~h}$. The (311) peak remained at $56.3^{\circ}$ until $4 \mathrm{~h}$, and then began to shift to a higher angle and reached $59.1^{\circ}$ after $45 \mathrm{~h}$ of milling. The gradual shift from 8 to $45 \mathrm{~h}$ demonstrates that the fine ceria

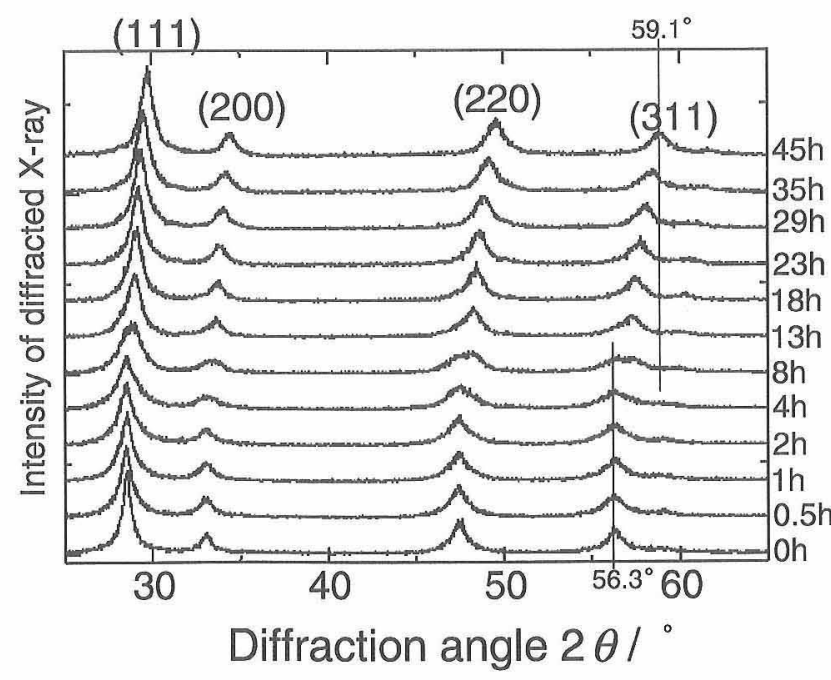

Fig. 1. X-ray diffraction patterns of fine ceria powder before and after milling. This figure is referenced from a previous paper ${ }^{2)}$ and has been slightly modified. powder reacted with the worn zirconia powder uniformly and that the composition of the ceria-zirconia solid solution was maintained uniformly as a whole. The reason for the remaining diffraction lines in the initial stage of milling is thought to be that it takes a certain amount of time for 10 $\mu \mathrm{m}$ of the agglomerate of fine ceria powder to break down below the critical particle size at which worn zirconia particles can dissolve in ceria particles.

The diffraction pattern of the coarse ceria powder reveals that the original diffraction lines from the high-purity ceria remains steady without any shift even after $44 \mathrm{~h}$ of milling (Fig. 2, (311) of original $\mathrm{CeO}_{2}$ ), and that new diffraction lines appear at a higher angle than the original lines and are separate from the original ones. The new lines are evident at the milling time of $36 \mathrm{~h}$ (Fig. 2, (311) of $\mathrm{CeO}_{2}-\mathrm{ZrO}_{2}$ solid solution). The new lines increase in intensity with the decrease of the original ones, with the progress of milling. The lines are all indexed to those of the solid solution of ceria and zirconia. The diffraction lines of the solid solution appear to increase without a gradual shift from the original one. One of them appears suddenly at the angle of $58.2^{\circ}$, indexed as (311) diffraction line, and increases its intensity without making any shift. This indicates that the solid solution is hardly formed before the milling time of approximately $27 \mathrm{~h}$, and also that the solid solution is formed at the composition corresponding to the diffraction angle of $58.2^{\circ}$, or the lattice constant of $0.527 \mathrm{~nm}$.

Figure 3 is referenced from our previous paper.5) The specific surface area of the coarse ceria powder milled for $44 \mathrm{~h}$ is $45 \mathrm{~m}^{2} / \mathrm{g}$, as shown in Fig. 3. The area, $45 \mathrm{~m}^{2} / \mathrm{g}$, corresponds to the average grain size of $21 \mathrm{~nm}$, assuming the powder as spherical. The half-width of the diffraction line of the original ceria powder increases gradually with the milling time, and it reaches approximately $0.55^{\circ}$ for the line of (311) at the milling time of $27 \mathrm{~h}$, and $0.70^{\circ}$ at the time of $44 \mathrm{~h}$. Applying Scherrer's formula to the half-width, the grain size of the original ceria was estimated as $28 \mathrm{~nm}$ at the time of $27 \mathrm{~h}$, and $21 \mathrm{~nm}$ at the time of $44 \mathrm{~h}$. The crystallite size of the original ceria powder (coarse), estimated by Scherrer's formula, is shown in Fig. 4 as a function of milling time. The size is in good agreement with that estimated from the surface area (Fig. 3). The specific surface area of the coarse ceria powder is $4 \mathrm{~m}^{2} / \mathrm{g}$, which corresponds to the diameter of $200 \mathrm{~nm}$. The diameter estimated from the halfwidth of the X-ray diffraction peak is also $200 \mathrm{~nm}$. These values are in good agreement. Thus, the crystallite size of

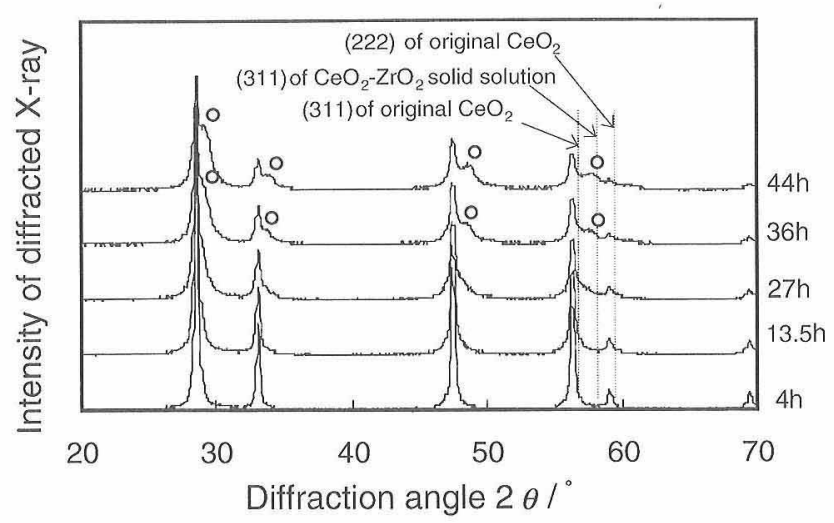

Fig. 2. X-ray diffraction patterns of ceria powder after a given milling time, using $\mathrm{Cu} \mathrm{K} \alpha$.

$\mathrm{O}$ represent peaks from $\mathrm{CeO}_{2}-\mathrm{ZrO}_{2}$ solid solution. Starting material: ceria powder; milling media: zirconia; dispersant: ethanol; rotational speed: $4200 \mathrm{rpm}$ 


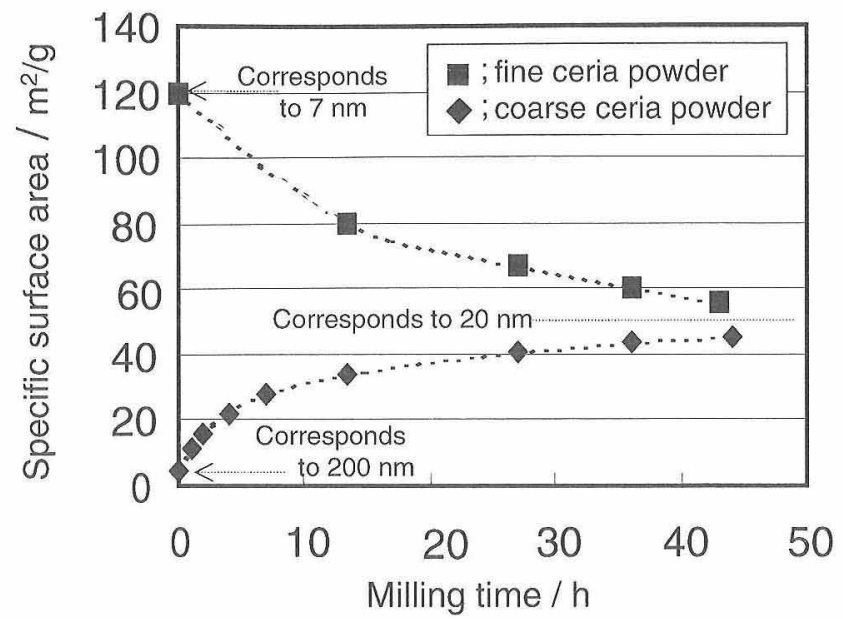

Fig. 3. Specific surface area of fine and coarse ceria powder before and after milling. This figure is referenced from a previous paper. ${ }^{5)}$

the coarse ceria powder is $200 \mathrm{~nm}$. After the agglomerate of the powder disappears, the crystallite size corresponds to the particle size calculated from the specific surface area. The solid solution can be clearly detected at the milling time of $36 \mathrm{~h}$. At that point, the grain size of the coarse ceria powder reaches approximately $22 \mathrm{~nm}$ on average, using any method of estimation. The decreasing rate of crystallite diameters of the original ceria powder (coarse) becomes small between 36 and $44 \mathrm{~h}$ of milling as shown in Fig. 4 . The crystallite size appears to asymptotically approach $20 \mathrm{~nm}$. This shows that the original ceria particle smaller than 20 $\mathrm{nm}$ reacts with zirconia, yielding the solid solution, and that the intensity of the peak of original ceria decreased with no further broadening than $0.70^{\circ}$ after $36 \mathrm{~h}$ of milling in Fig. 2. The critical size, $20 \mathrm{~nm}$, calculated from the half-width of the XRD peak, at which ceria and zirconia particles begin to react in the milling agrees with the diameter, $20 \mathrm{~nm}$, estimated from the specific surface area (Fig. 3).

A schematic diagram of the dissolving process of the coarse or fine ceria powder with worn zirconia powder is

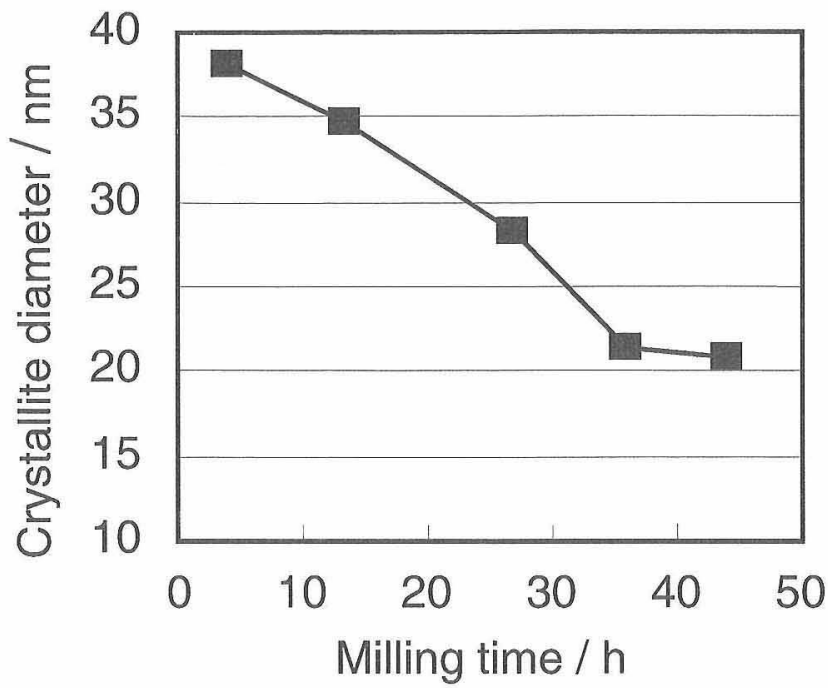

Fig. 4. Crystallite diameter of original ceria powder (coarse) calculated by Scherrer's formula as a function of milling time.

shown in Fig. 5. For the case of fine ceria powder, its agglomeration is easily dispelled in the initial stage of milling. Almost all particles are less than the critical size of $20 \mathrm{~nm}$. As milling proceeds, zirconia particles were added due to wearing of the milling media and they dissolved into ceria particles. The worn zirconia powder dissolves promptly with ceria particles less than the critical size. The powder being milled changed into the ceria-zirconia solid solution as a whole. The solid solution particles finally reach the critical size of $20 \mathrm{~nm}$. In contrast, the particle (crystallite) size of the coarse ceria powder is larger than the critical size, and the large crystallites are difficult to break into small pieces under $20 \mathrm{~nm}$ at once. They are partially broken down into smaller particles, and only the broken-down particles dissolved with worn zirconia particles form a solid solution of ceria and zirconia. The solid solution particles enlarge to 20 $\mathrm{nm}$. The original coarse ceria powder remained until $44 \mathrm{~h}$.

For the milling of coarse ceria powder, the ceria-zirconia solid solution formed exhibits a diffraction angle of $58.2^{\circ}$ of

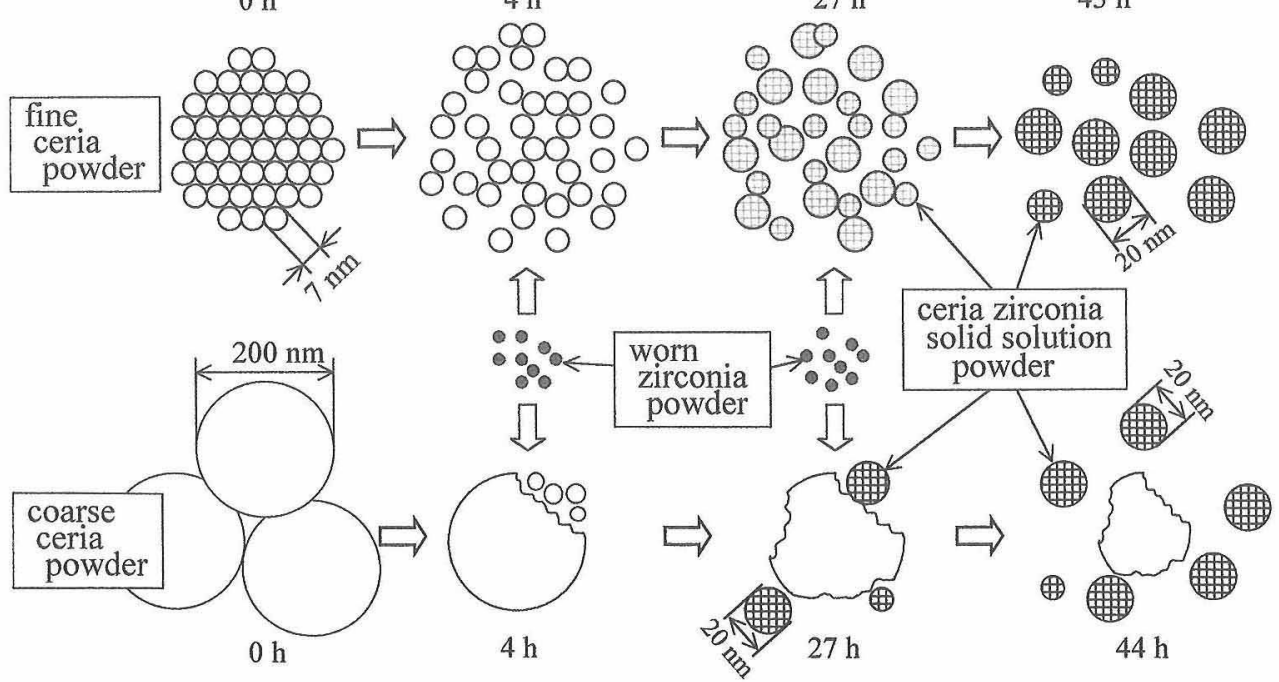

Fig. 5. Schematic diagram of the dissolving process of coarse or fine ceria powder with worn zirconia powder. 
the (311) plane in Fig. 2. The diffraction angle of $58.2^{\circ}$ of (311) of the solid solution corresponds to the composition of $50 \mathrm{~mol} \% \mathrm{CeO}_{2}-50 \mathrm{~mol} \% \mathrm{ZrO}_{2}$, which is shown in our previous paper. ${ }^{5)}$ The composition occurred predominantly during the milling of the coarse ceria powder. The reason for the preferred occurrence of the composition was considered to be that the supply rate of broken-down ceria particles less than the critical particle size from the coarse ceria powder and worn zirconia powder from the milling media might be almost the same.

As mentioned above, the specific size of each particle, which is dissolving, cannot be measured by the X-ray diffraction method or the specific surface area measurement. However, the value of $20 \mathrm{~nm}$, which is considered to be the critical particle size, was found asymptotically by the two methods, which were in good agreement. Therefore, the value of the critical particle size might be reliable. The important point in fabricating a new material by this process is to use starting materials having a smaller crystallite size than the critical particle size.

\section{Conclusions}

(1) The reaction that forms the ceria-zirconia solid solution from large ceria particles $\left(4 \mathrm{~m}^{2} / \mathrm{g}\right)$ begins after $27 \mathrm{~h}$ of milling, which is much longer than the beginning of the reaction of the fine ceria powder.

(2) The critical particle size of ceria powder to begin the reaction with zirconia is thought to be approximately 20 $\mathrm{nm}$, which was found asymptotically by two methods, X-ray diffraction and specific surface area measurements.

(3) The reason for the preferred occurrence of the solid solution, $50 \mathrm{~mol} \% \mathrm{CeO}_{2}-50 \mathrm{~mol} \% \mathrm{ZrO}_{2}$ is considered to be that the supply rate of ceria particles smaller than the critical particle size from the coarse ceria powder and the worn zirconia powder from the milling media might be almost the same, and that the two kinds of fine powders react with each other uniformly.

Acknowledgment The authors express sincere thanks to Dr. Osami Kamigaito for his discussion throughout the present work and for his help in the preparation of this manuscript. Thanks should be given also to Drs. Toshio Kurauchi and Hidero Takahashi for their encouragement throughout this work.

\section{References}

1) Japanese unexamined patent publication, 333116 (1996)

2) Suda, A., Kandori, T., Terao, N., Ukyo, Y., Sobukawa, H. and Sugiura, M., J. Mater. Sci. Lett., 17, 89-90 (1998).

3) Suda, A., Sobukawa, H., Suzuki, T., Kandori, T., Ukyo, Y. and Sugiura, M., J. Ceram. Soc. Japan, 109, 177-80 (2001).

4) Trovarelli, A., Zamar, F., Llorca, J., Leitenburg, C., Dolcetti, G. and Kiss, J. T., J. Catal., 169, 490-502 (1997).

5) Suda, A., Kandori, T., Ukyo, Y., Sobukawa, H. and Sugiura, M., J. Ceram. Soc. Japan, 108, 473-77 (2000).

6) Kato, M., "X-ray Diffraction Analysis," Uchida Rokakuho, Tokyo (1990) pp. 247-48 [in Jananese]. 